\title{
Mucous gland adenoma of the bronchus in a 5-year-old child: case report and review of the literature
}

\author{
Adenoma de células mucosas do brônquio em criança de 5 anos: relato de caso e revisão da literatura
}

Luiz Cesar Peres

Eumenia Costa da Cunha Castro

\begin{tabular}{l|l}
\multicolumn{1}{c|}{ key words } & abstract \\
Adenoma & Mucous gland adenoma is a rare benign tumor arising from the mucous secreting glands of the \\
Adenoma of the bronchus & $\begin{array}{l}\text { larger airway mucosa. The majority of the cases are seen in the bronchus, but it has also been } \\
\text { described in the trachea or peripheral airways. The tumor is composed of mucus-secreting cells, } \\
\text { Mucous gland adenoma } \\
\text { Child }\end{array}$ \\
$\begin{array}{l}\text { usually forming glands that grow into the lumen as to form an obstructive mass. There is no } \\
\text { predilection for sex or age. We report here a case seen in a 5-year-old girl, to our knowledge the } \\
\text { youngest in the consulted literature, who presented to Hospital das Clínicas of Faculdade de } \\
\text { Medicina de Ribeirão Preto for investigation and treatment of recurrent pneumonia and lung } \\
\text { atelectasis. Bronchoscopy showed a mass obstructing the lower left bronchus and a biopsy of the } \\
\text { lesion revealed a benign, although uncharacteristic lesion. Surgical removal of the affected segment, } \\
\text { the recommended treatment for this benign lesion, evidenced a mucous gland adenoma. The child } \\
\text { recovered well and was completely free of disease when she was lost for follow-up when she was } 6 \\
\text { years old. }\end{array}$
\end{tabular}

resumo

O adenoma de células mucosas é uma neoplasia benigna rara que se origina nas glândulas da mucosa das vias aéreas maiores. A maioria dos casos é vista nos brônquios, mas já foram descritos casos na traquéia e nas vias respiratórias distais. O tumor é constituído por células mucossecretoras, que geralmente formam glândulas que crescem para dentro da luz, formando massa obstrutiva. Não há predileção por sexo ou idade. Nós relatamos aqui um caso observado em uma menina de 5 anos, o mais jovem relato na literatura consultada, que se apresentou no Hospital das Clínicas da Faculdade de Medicina de Ribeirão

Preto para investigação e tratamento de pneumonia recorrente e atelectasia do pulmão. O exame broncoscópico mostrou massa obstruindo o brônquio inferior esquerdo e a biópsia revelou lesão benigna incaracterística. A remoção cirúrgica do segmento afetado, que é o tratamento recomendado para esta lesão benigna, evidenciou um adenoma de células mucosas. A criança recuperou-se bem e estava completamente livre de doença quando deixou o seguimento com 6 anos de idade.
1. Associate professor of the Pathology Departament of Faculdade de Medicina de Ribeirão Preto/Universidade de São Paulo. 2. Reader professor of Ceneral Pathology of Faculdade de Medicina do Triângulo Mineiro. This work was conducted at the Departamento de Patologia, Faculdade de Medicina de Ribeirão Preto/Universidade de São Paulo, Ribeirão Preto, São Paulo, Brazil. 


\section{Introduction}

Mucous gland adenoma is a rare benign tumor originated from the mucous secreting glands of the larger airway mucosa (7). This tumor, first reported in 1882 by Muller as a pathologic entity separate from carcinoma of the lung (7), was first named bronchial adenoma arising from mucous gland. Different nomenclature and origin of the tumor over the years have brought confusion to the pathologists' interpretation of the lesion (7, 10-12, 14, $15)$. This tumor has also been previously named adenomatous polyp (12), adenoma of mucous gland type (15), bronchial cystadenoma (3) or papillary cystic adenoma (13), but now the name mucous gland adenoma of the bronchus is preferred $(1,4,6)$. This tumor has incorrectly been described under the term bronchial adenoma with three other low malignant neoplasms, namely: cylindromas, carcinoid and mucoepidermoid carcinoma $(5,7)$, and many authors have already stressed the inadequacy of such designation $(1,5,6)$. It is seen in all age groups with no sex predilection (13). We report here a case of mucous gland adenoma of the bronchus in a 5 -year-old patient, the youngest in English literature, as far as we know.

\section{Case report}

The patient was a 5-year-old white female child who presented an episode of fever and malaise for 20 days interpreted as a common cold. A chest X-ray showed atelectasis of the superior lobe of the left lung and pneumonia in the inferior one. She was treated with ampicilin without clinical change and so she was referred to the University Hospital. A new chest X-ray showed left lung condensation, atelectasis and pleural effusion. She was treated with crystalline penicillin recovering well from the pneumonia with persistence of the atelectasis. One month later she had another episode of pneumonia and was admitted to Hospital das Clínicas of Faculdade de Medicina de Ribeirão Preto for treatment and investigation. Chest X-Ray revealed atelectasis and pneumonia of the left lung with displacement of the mediastinum to the left. Bronchoscopy revealed an intraluminal mass attached to the wall of the left inferior lobe bronchus obstructing almost completely the lumen. A small superficial biopsy showed a benign neoplasm and a surgical resection of a segment of the inferior lobe bronchus was performed. During the surgery, it was noted that the tumor obstructed not only the left inferior lobe but also the superior lobe and the main left bronchus.
The surgical specimen consisted of a segment of bronchus measuring $1.5 \mathrm{~cm}$ in length with a mean diameter of $0.8 \mathrm{~cm}$. The wall measured $0.2 \mathrm{~cm}$ and showed no abnormality. A nodular mass of $0.7 \mathrm{~cm}$ in diameter exhibiting a smooth surface emerged from the mucosa and filled the lumen. The cut surface of the lesion showed a glistening homogeneous tissue.

Histology of hematoxylin and eosin (H\&E) stained sections of this polypoid neoplasm (Figure $1 \mathbf{A}$ ) revealed that it was composed of large vacuolated cells with oval nuclei displaced to the periphery (Figure 1B). The cells were immersed in a basophilic matrix. Delicate fibrous septa with blood vessels separated the cells in ill-defined lobules evidenced by the reticulin staining (Figure 1C). Well-formed mucus-secreting glands were only occasionally identified. The mucus was PAS positivediastase resistant and Alcian-blue $\mathrm{pH} 2.5$ - but not $\mathrm{pH} 1.0$ positive, the same as the remaining mucous glands of the submucosa. The neoplasia was restricted to the submucosa and close to normal mucous glands. No mitosis, hemorrhage or necrosis was identified. There was erosion and squamous metaplasia of the surface of the epithelium. The immunohistochemical study, presented in Table 1, was performed with the Streptavidin-Biotin method using the following antibodies: $A E 1 A E 3$ (Boehringer $\left.{ }^{\circledR}\right)$, CEA (Dako $\left.{ }^{\circledR}\right)$, EMA (Dako $\left.{ }^{\circledR}\right)$, NSE (Dako $\left.{ }^{\circledR}\right), 34 \mathrm{bE} 12$ (Dako ${ }^{\circledR}$ ) and 35bH11 (Dako $\left.{ }^{\circledR}\right)$. Final diagnosis was mucous gland adenoma of the bronchus.

The child recovered well and was thriving after 16 months, when she was lost for follow up, with a normally expanding left lung and a normal looking bronchial lumen by bronchoscopy.

\section{Discussion}

Mucous gland adenoma has been identified from childhood to adult life and the previous youngest patient in the consulted literature was aged 7 (Table 2). This is a benign lesion and should be clearly separated from the other low malignant tumors that may arise in this region $(3,12,14$, 15) - carcinoid, cylindroma and mucoepidermoid tumour incorrectly referred to as bronchial adenoma (5).

It is usually seen in the main bronchi although there are reports of tumors located in the peripheral airways (15) or even in the trachea (6). In the present case, the lesion was located in the left inferior lobe bronchus bulging to obstruct the main left bronchus. Because of its intraluminal growth, these lesion may induce a valvular 


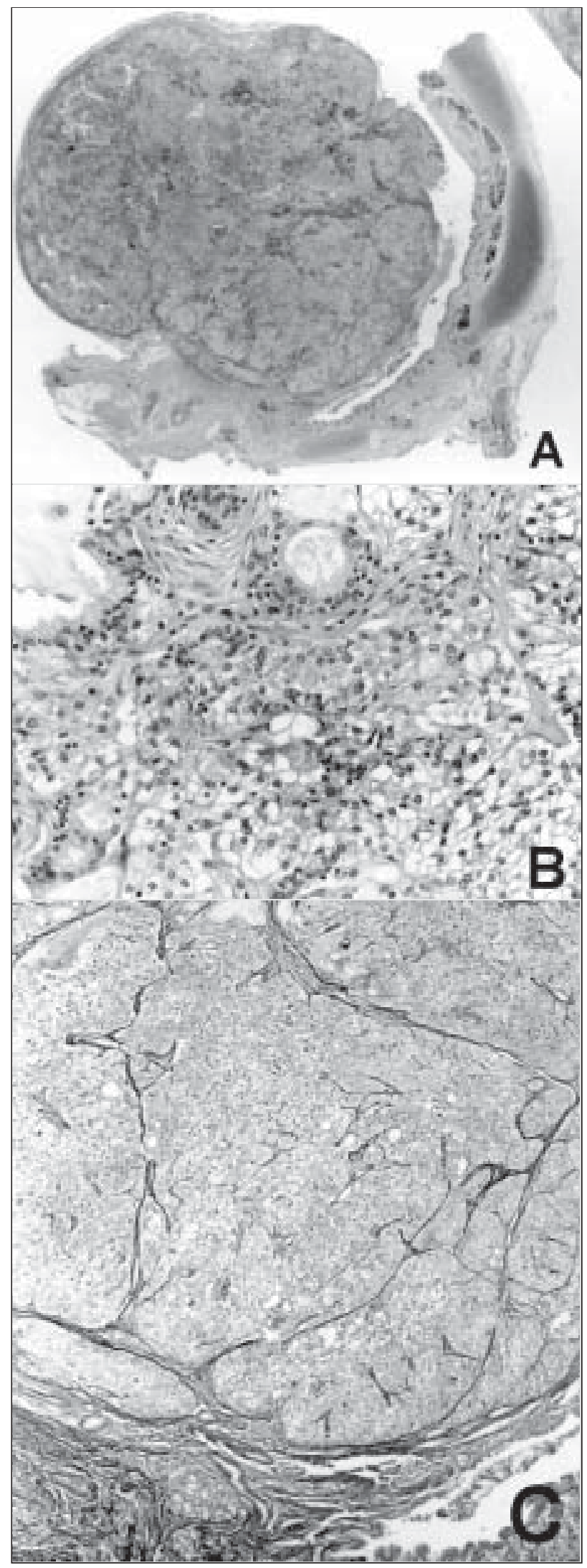

Figura - Photomicrography of the mucous gland adenoma of the bronchus. Note the large tumor mass bulging into the lumen of the bronchus and in continuity with the mucosa (A). The tumor is composed of large vacuolated cells in a basophilic matrix with some well formed glands $(B)$, separated by delicate fibrous septa seen with the reticulin stain (C). Original magnification: $A=10 x ; B=100 x ; C=50 x$ mechanism of two different types: ball valve, in which the tumor mass blocks the airway in inspiration and opens in expiration, and check valve, in the opposite way (12). In the present case, the first mechanism was the most likely since the patient developed atelectasis of the left lung. Pedunculated lesions may also change their position with body posture modifying the patient's symptomatology.

Clinically, patients may exhibit signs of a low growing intrabronchial tumor reflected by cough, wheezing, hemoptisis, recurrent pneumonia, emphysema (12), asthma (13) and atelectasis (12) until a definite diagnosis is made by bronchoscopy and biopsy. In our case, a small superficial biopsy showed only squamous metaplasia overlying a lesion made up of large vacuolated cells. A provisional diagnosis of a benign hamartomatous lesion was offered.

Histologically, mucous gland adenoma of the bronchus may be of three different types: orderly tubular glands, papillary and cystic adenomas (10) or, as in our case, small cystic mucinous lesion (13). The mucus is histochemically similar to the normal epithelial mucin (9). Our results show that the mucus was PAS positive-diastase resistant and Alcian blue $\mathrm{pH}$ 2.5- but not $\mathrm{pH}$ 1.0-positive as the mucous gland of the remaining normal mucosa. Squamous metaplasia or erosion of the respiratory epithelium is frequently seen (14-15), as in our case. The erosion explains the common hemorrhage and hemoptisis seen in these patients.

The immunohistochemical study was consistent with the literature (9) (Table 2). Tumor cells were positive for AE1AE3, CEA and EMA in the same way as the normal mucous gland cells but presented a weaker positivity for $34 \mathrm{bE} 12$ and $35 \mathrm{bH} 11$. On the other hand, CEA was positive in the vacuolated tumor cells as well as in the mucus.

The histochemical and immunohistochemical patterns exhibited by this tumor may help in characterizing a biopsy specimen taken from a similar lesion as derived from the normal bronchial mucous glands (Table 2).

The tumor does not extend beyond the bronchial cartilage, although it may distort it. There are no mitosis, hemorrhage, necrosis, and infiltration of normal tissues or metastasis, characterizing this lesion as a completely benign tumor. The treatment of choice is total local excision (3-4) with the most conservative technique as in this case. Our patient was 6 years old when lost for followup completely free of disease after 16 months of the surgical treatment. 


\section{Table 1 Immunohistochemical study of the mucous gland adenoma of the bronchus}

\begin{tabular}{lcccc}
\hline & Tumor glands & Vacuolated cells & Normal epithelium & Mucus \\
AE1 AE3 & $H$ & + & + & - \\
CEA & $H$ & + & + & + \\
EMA & $H$ & $H$ & + & - \\
NSE & - & - & - & - \\
$34 \beta E 12$ & + & - & + & - \\
$35 \beta H 11$ & + & - & + & - \\
\hline
\end{tabular}

++: diffuse; +: focal; -: no reaction; AE1AE3: cytokeratin pool; CEA: carcinoembryonic antigen; EMA: epithelial membrane antigen; NSE: neuron specific enolase; 34ßE12: light weight cytokeratin; 35BH11: heavy weight cytokeratin.

\section{Table 2 Review of the English literature of mucous gland adenoma in children}

\begin{tabular}{|c|c|c|c|c|c|c|}
\hline Case & Reference & Age & Macroscopy & Microscopy & Histochemestry & IH \\
\hline $1,2,3$ & $\begin{array}{l}\text { Kroe \& Pitcock, } \\
1967 \text { (9) }\end{array}$ & $\begin{array}{l}11,14 \\
8^{1 / 2}\end{array}$ & No description & No description & No description & NO \\
\hline 4 & $\begin{array}{c}\text { Emory et al., } \\
1973 \text { (4) }\end{array}$ & 14 & $\begin{array}{l}\text { Oval, irregularly } \\
\text { shaped,pedunculated } \\
\text { polypoid lesion } \\
(1.1 \times 1 \mathrm{~cm})\end{array}$ & $\begin{array}{l}\text { Irregularly shaped } \\
\text { aggregate of cells } \\
\text { forming mucus filled, } \\
\text { intact, tubular or } \\
\text { glandular-like spaces }\end{array}$ & $\begin{array}{l}\text { Mucicarmine } \\
\text { positive }\end{array}$ & NO \\
\hline 5,6 & $\begin{array}{c}\text { Heard et al., } \\
1985 \text { (8) }\end{array}$ & 7,12 & $\begin{array}{l}\text { Single mass } \\
\text { ( } 2 \text { to } 6.5 \mathrm{~cm}) \text {, firm, cut } \\
\text { surface pale grey and } \\
\text { slightly translucent } \\
\text { Compression but no } \\
\text { infiltration of the lung }\end{array}$ & $\begin{array}{l}\text { Acini and ducts } \\
\text { resembling those of } \\
\text { normal bronchial gland } \\
\text { Main tumor cell: } \\
\text { mucous epithelial } \\
\text { cell of the gland }\end{array}$ & $\begin{array}{l}\text { Mucus positive for } \\
\text { mucicarmine and PAS; } \\
\text { focally alcianophilic } \\
\text { with Alcian blue- } \\
\text { diastase-PAS } \\
\text { sequence and PAS } \\
\text { elsewhere }\end{array}$ & NO \\
\hline 7 & $\begin{array}{l}\text { Dickstein et al., } \\
1993 \text { (2) }\end{array}$ & 12 & $\begin{array}{l}\text { Polypoid lesion } \\
(1.5 \times 0.6 \mathrm{~cm}) \text { with base } \\
\text { attached to the wall of } \\
\text { the bronchus. Bronchial } \\
\text { wall dilatation distal to } \\
\text { the tumor forming a } \\
\text { cyst-like structure filled } \\
\text { with mucinous material }\end{array}$ & $\begin{array}{l}\text { Tumor composed of } \\
\text { well differentiated } \\
\text { monomorphic columnar } \\
\text { cells, forming microcystic } \\
\text { structures and acini in } \\
\text { a fibrotic stroma. No } \\
\text { evidence of mitotic } \\
\text { figures or invasion }\end{array}$ & NO & NO \\
\hline 8 & $\begin{array}{l}\text { Peres et al. } \\
\text { (present case) }\end{array}$ & 5 & $\begin{array}{l}\text { Smooth surfaced nodular } \\
\text { mass }(0.7 \mathrm{~cm}) \text { attached to } \\
\text { the bronchial mucosa } \\
\text { Glistening homogeneous } \\
\text { cut surface }\end{array}$ & $\begin{array}{l}\text { Large vacuolated } \\
\text { tumor cells in a } \\
\text { basophilic matrix, } \\
\text { separated ill } \\
\text { defined lobules by } \\
\text { delicate fibrous septa. } \\
\text { Tumor restricted to the } \\
\text { submucosa and close to } \\
\text { normal mucous glands. } \\
\text { No mitosis or invasion }\end{array}$ & $\begin{array}{l}\text { Mucus PAS } \\
\text { positive-diastase } \\
\text { resistant and Alcian- } \\
\text { blue pH } 2.5 \text { - but not } \\
\text { pH } 1.0 \text {-positive, the } \\
\text { same as the remaining } \\
\text { mucous glands of the } \\
\text { submucosa }\end{array}$ & $\begin{array}{l}\text { Tumor cells } \\
\text { positive for } \\
\text { AE1AE3, CEA } \\
\text { and EMA like } \\
\text { the normal } \\
\text { mucous gland } \\
\text { cells. Weak } \\
\text { positivity for } \\
34 \beta \text { E12 and } \\
35 \beta H 11 \text {. Mucus } \\
\text { and vacuolated } \\
\text { tumor cells } \\
\text { positive for } \\
\text { CEA }\end{array}$ \\
\hline
\end{tabular}




\section{References}

1. Allen Jr, M.S. et al. Mucous gland adenoma of the bronchus. J.Thor. Cardiovasc. Surg., 67(6): 966-8, 1974.

2.D ickstein, P.j. et al. Bronchial mucous gland adenoma presenting as bronchogenic cyst. Ped. Pulmonol. 16: 370-4, 1993.

3 Edwards, C.W. \& Mathhews, H.R. Mucous gland adenoma of the bronchus. Thorax, 36:147-8, 1981.

4. Emory, W.B. et al. Mucous gland adenoma of the bronchus. Am. Rev. Resp. Dis., 108: 1407-10, 1973.

5. England, D.M .\& H ochholzer, L.Truly benign "bronchial adenoma". Report of 10 cases of mucous gland adenoma with immunohistochemical and ultrastructural findings. Am. J. Surg. Pathol., 19(8): 887-99, 1995.

6. Fergusson, C .J. \& C leeland, J.A. Mucous gland adenoma of the trachea: case report and literature review.J.Thor. Cardiovasc. Surg., 95:347-50, 1988.

7. Gilman, G.A. et al. Mucous gland adenoma of the bronchus. Report of a case with study of secretion. Am. J. Clin. Path., 26: 151-4, 1956.
8. H eard, B.E. et al. Patho logy of seven mucous gland adenomas of the bronchial glands with particular reference to ultrastructure. H istopathol., 9: 687-01, 1985.

9. Kroe, D.J. \& Pitcock, J.A. Benign mucous gland adenoma of the bronchus. Arch. Pathol., 84: 539-42, 1967.

10. Markel,S.F.et al. N eo plasms of bronchus commonly designated as adenomas. Cancer, 17(5): 590-608, 1964.

11. Ramsey, J.H . \& Reimann, D.L. Bronchial adenomas arising in mucous glands. Illustrative case. Am. J. Pathol., 29: 339-51, 1953.

12. Rosenblum, P. \& Klein, R.I. A denomato us polyp of the right main bronchus producing atelectasis. J. Ped., 7: 791-6,1935.

13. Smith, A.J. Benign epithelial tumours of the bronchus. South. Med. J., 58: 1535-9, 1965.

14. Sniffen, R.C . et al. Mucoepidermoid tumors of the bronchus arising from surface epithelium.Am.J.Pathol.,34:671-83,1958.

15.W einberger, M .A . et al.Peripheral bronchial adenoma of mucous gland type. J.Thor. Surg., 29:626-35, 1955. 